\title{
RESPON MUSLIM INDONESIA TERHADAP GERAKAN ISLAMISME DI TIMUR TENGAH: KASUS HAMAS DAN KONFLIK PALESTINA
}

\author{
Mulawarman Hannase \\ Dosen Program Pascasarjana Institut PTIQ Jakarta
}

\begin{abstract}
This paper will examine how the Indonesian Muslim community which consist many streams of religious and social organizations to respond the crisis that involved recently in the Gaza Strip involving Hamas Islamism group. The main issue highlighted in this paper is whether Hamas has network in Indonesia? How the influence of Hamas network in Indonesia towards the development of Islamic fundamentalist thought in Indonesia? Is the Muslim community in Indonesia has the same view in addressing the conflict in the Gaza Strip?This article will use two approaches; the theological and political approach. Theological approach is used to see similarity of the doctrine espoused byHamas with some Islamists in Indonesia. Moreover, this approach is also used to distinguish between Hamas ideological doctrine with the view of other Islamist groups grown today. While political approaches used to answer the question how the political support of the Indonesian people against the Israeli Palestinian conflict, in particular the conflict between Hamas and Israel. Based on review of the above problems, it can be found that from an ideological perspective, Hamas has a strong network in various countries, including Indonesia. Whereas the model of Indonesian Muslims support to the Gaza crisis, at least occurs in three forms: pan-Islamism, diplomatic support and humanitarian support.
\end{abstract}


162 Rausyan Fikr, Vol. 12 No.2 Desember 2016: 161 - 180

Keywords: Indonesian Community, Islamism, Hamas, Politic, Conflict.

\section{PENDAHULUAN}

Hamas merupakan sebuah kelompok Islamis berpusat di Jalur Gaza. Dalam kehidupan sosial politik Palestina, Hamas banyak membantu korban perang dengan Israel dan kadangkala terlibat dalam perlawanan melawan Israel. Oleh karenanya Glenn E. Robinson menganggap Hamas sebagai sebuah gerakan sosial. ${ }^{1}$ Selama intifada berlangsung, Hamas telah memberikan konstribusi besar dalam peningkatan kondisi sosial dan keagamaan masyarakat, peningkatan infrastruktur di bidang pendidikan di Jalur Gaza dan West Bank.Garakan Hamas sangat dikenal dengan gerakan amal untuk kemanusiaan.Bagi masyarakan Palestina di Jalur Gaza dan West Bank, Hamas merupakan Gerakan Sosial penyelamat karena ideologi dan solidaritasnya yang tinggi terhadap bangsa Palestina. $^{2}$

Dalam persoalan hubungan Palestina dan Israel, Hamas dalam sikap dan pandanganya tegas terhadap Israel sehingga keduanya banyak terlibat dalam konfrontasi militer.Dalam hal ini, Mohammed Hafez menyebutnya sebagai gerakan yang tidak mau berkompromi uncompromising movement.Dalam pandangan Hamas, konflik antara Israel dan Palestina merupakan konflik agama dan peradaban. Alasan Hamas sehingga menempatkan konflik Palestian sebagai konflik agama karena tentara Israel tidak mengecualikan tempat-tempat suci ummat Islam -seperti Mesjid Aqsa- dalam

\footnotetext{
${ }^{1}$ Baca Glenn E. Robinson, "Hamas as Social Movement", dalam Quintan Wiktorowicz, Islamic Activism: A Social Movement Theory Approach (Indiana: Indiana Unirversity Press, 2004), 122.

${ }^{2}$ Kasjim Salenda, Terorisme dan Jihad dalam Perspektif Hukum Islam(Jakarta: Badan Litbang dan Diklat Departemen Agama RI, 2009), 189.
} 
Mulawarman, Respon Muslim Indonesia terhadap Gerakan Islamisme|

163

serangan-serangan militernya. Hamas tidak tertarik untuk menempuh jalan damai penyelesaian konflik, akan tetapi lebih cenderung menggunakan cara-cara militansi. ${ }^{3}$

Dalam konteks Indonesia, literatur yang secara detail dan komperhensif membahas hubungan Hamas dengan Indonesia hampir tidak bisa ditemukan. ${ }^{4}$ Namun, perhatian masyarakat Indonesia terhadap isu ini sangatlah besar mengingat banyaknya ditemukan di berbagai media cetak maupun online di negeri ini, artikel, opini dan komentar seputar bagaimana peran Indonesia dan apa yang seharusnya dilakukan pemerintah dan rakyat Indonesia terhadap konflik Israel Palestina khususnya terhadap perang gaza yang hampir satu dekade berulang kali terjadi. Mengenai hubungan Indonesia dengan Palestina khususnya Hamas di Gaza, setidaknya bisa ditinjau dari tiga pendekatan yaitu dari sudut pandang ideologis atau pan Islamisme, dari sudut pandang politik serta dari sudut pandang humanisme.

\section{PERSPEKTIF PAN-ISLAMISME}

Dari sudut pandang pan Islamiseme, tidak bisa dipungkiri bahwa hubungan antara masyarakat Indonesia sangatlah kuat dengan isu perjuangan Hamas di Palestina. Dari segi kuantitas, Indonesia merupakan negara yang mempunyai jumlah penduduk muslim terbesar di dunia dengan berbagai aliran dan corak

\footnotetext{
${ }^{3}$ Khalid al-Hurub, Hamas, al-Fikr wa al-Mumarasah (Beirut: Mu'assasah al-Dirasat al-Filisttiyyahm 1999), 47.

${ }^{4}$ Sebenarnya literatur yang mengkaji masalah Palestina dari perspektif historis cukup banyak.Namun tidak ada yang secara spesifik mengkaji hubungan Indonesia dengan Hamas kecuali artikel dan komentar di media. Literatur tersebut di antaranya, Trias Kuncahyono, Jalur Gaza: Tanah Terjanji, Intifada dan Pembersihan Etnis (Jakarta: Kompas, 2009), Bawono Kumoro, Hamas, Ikon Perlawanan Islam Terhadap Zionisme Israel (Jakarta: Mizan, 2009).
} 
164 Rausyan Fikr, Vol. 12 No.2 Desember 2016: 161 - 180

keagamaan yang sangat beragam. Meskipun sangat beragam, mayoritas muslim di Indonesia merupakan muslim sunni dengan dua ormas Islam besar yaitu Muhammadiyah ${ }^{5}$ dan Nahdatul Ulama (NU) ${ }^{6}$. Kedua Organisasi Masyarakat (Ormas) masing-masing menegaskan bahwa masalah Palestina harus didukung oleh umat Islam Indonesia agar negara ini bisa merdeka dari belenggu Israel.Kedua ormas inipun cenderung melihat masalah ini sebagai persoalan ideologis yaitu berkaitan dengan identitas dan kepentingan Islam di dunia. ${ }^{7}$ Kedua ormas ini juga menginginkan bagaimana umat Islam mengalami kebangkitan dan kejayaan tanpa terbelenggu oleh entitas dan negara lain yang disebut dengan pan Islamisme. $^{8}$

${ }^{5}$ Salah satu bentuk dukungan nyata Muhammadiyah adalah bantuan yang diberikan kepada Palestina senilai 2,5 Milyar pada tanggap 9 September 2014. Bantuan tersebut diserahakan langsung ketua Muhammadiah Din Syamsuddin kepada Dubes Palestina di kantor Pengurus Pusat Muhammadiyah Jakarta. Lihat dalam http://www.muhammadiyah.or.id/id/news-3891-detail-muhammadiyahbantu-palestina-rp-25-milyar.html, diakses 20 Februari 2015.

${ }^{6} \mathrm{KH}$. Hasyim Muzadi pernah mengatakan bahwa masalah Palestina bukanlah masalah bangsa Palestina atau Arab saja, akan tetapi merupakan masalah umat Islam secara keseluruhan. Hal itu disampaikan saat kunjungan delegasi perdamaian PBNU ke Lebanon Selatan yang disambut oleh Imam Mesjid al-Quds Sheikh Qahir Hamud pada bulan Januari 2010.Baca dalam http://www.nu.or.id/a,public-m,dinamic-s, detail-ids,1-id,21169, diakses 20 Feruari 2015.

${ }^{7}$ Baik NU maupun Muhammadiyah dalam menyikapi isu Palestina dan krisis Gaza selalu mengidentikkannya dengan masalah umat islam secara keseluruhan sebagaimana telah disebutkan sebelumnya yaitu pernyataan $\mathrm{KH}$. Hasyim Muzadi.

${ }^{8}$ Banyak sekali makna dari Pan Islamisme ( اححاد الاسلام).Makna yang paling kuat adalah berasal dari ide Jamaluddin Afgani yang mempunyai pendangan menyatukan umat Islam secara politik. Namun, makna yang dikehendaki dalam konteks ini adalah Pan Islamisme sebagai bentuk dukungan umat Islam untuk memperjuangkan kemerdekaan umat Islam dimana pun. Untuk mengetahui asal-usul terminologi ini, lihat Dwight E. Lee, "Notes and 
Isu Palestina juga merupakan isu penting dalam pandangan para akademisi dan cendikiawan muslim di Indonesia. Dalam pandangan-pandangan mereka yang beragaman, isu Palestina kerap dikomentari dan dicarikan solusi penyelesaiannya meskipun terbatas pada tulisan di media. Para akademisi dan cendekiawan tersebut seperti, Ridwan Saidi, ${ }^{9}$ Azyumardi Azra, Zuhairi Misrawi, ${ }^{10}$ Hasibullah Sastrawi ${ }^{11}$ dan lainnya. Azyumardi Azra termasuk cendekiawan muslim yang sangat banyak memberikan opini dan komentar seputar kasus Palestina. Salah satu komentarnya yang terkini tentang kasus ini adalah, Azra optimis bahwa Indonesia bisa menjadi mediator penyelesaian krisis Palestina.Salah satu langkah posisitif untuk itu adalah rencana Presiden Jokowi membuka perwakilan Indonesia di Ramallah. ${ }^{12}$

Berbeda dengan kaum terpelajar dan para akademisi, masalah Palestina dalam alam pikiran masyarakat awam di Indonesia didominasi oleh dimensi teologis.Mereka kebanyakan tidak memahami masalah Palestina secara detail, seperti permasalah

SuggestionsThe Origin of Pan-Islamism", The American Historical Review, Vol. 47, No. 2, (t.t), 278-87.

${ }^{9}$ Karya Ridwan Saidi yang terkenal adalah Fakta dan Data Yahudi di Indonesia Dulu dan Kini (Jakarta: Khalifa, 2006).

${ }^{10}$ Salah satu komentar Zuhairi yang terkenal adalah ketika ia mengkritisi perayaaan Hamas atas kemenangan dalam perang 8 hari di Jalur Gaza 2006. Ia menganggap perayaan tersebut tidak tepat karena perang tersebut banyak menelan korban rakyat Gaza. Baca dalam http://news.fimadani.com/read/2012/11/23/kaderjil-dan-hti-kritisi-kemenangan-rakyat-gaza/.Diakses 21 Februari 2015.

${ }^{11}$ Komentar-komentar Hasibullah Sastrawi lebih banyak bersifat pesimis terhadap perdamaian Palestina. Dalam kemenangan Hamas di Gaza tahun 2012 misalnya, ia beranggapan bahwa kemenangan tersebut tidak akan berlangsung lama.

http://kompas.com/read/2012/12/04/02222290/Tantangan.Kemerdekaan.Palestina.

$12 \mathrm{http} / / /$ theglobejournal.com/politik/azyumardi-azra-indonesia-bisa-jadimediator-konflik-israel---palestina/index.php. Diakses 21 Februari 2015. 
Fatah dan Hamas. ${ }^{13}$ Ketika misalnya terjadi perang Gaza yang disiarkan secara langsung di televisi dan media massa lainnya, mereka memahami bahwa perang itu melibatkan semua unsur masyarakat dan milisi di Palestina. Padahal, perang yang banyak terjadi akhir-akhir ini di Jalur Gaza hanya melibatkan milisi Hamas dan masyarakat Gaza, meskipun tetap didukung secara moril oleh masyarakat Tepi Barat dan Palestina secara keseluruhan. Terlepas dari pemahaman mereka yang terbatas tentang konflik Palestina, muslim Indonesia sadar sepenuhnya bahwa masyarakat Palestina yang tertindas harus didukung karena berkaitan dengan harga diri dan marwah umat Islam. ${ }^{14}$

Dukungan tersebut bisa dilihat dari berbagai bentuk.Ketika dilaksanakan ibadah shalat jumat misalnya, sangat banyak ditemukan khatib yang menutup khutbahnya dengan mengajak para jamaah untuk mendoakan perjuangan rakyat Palestina. Apa yang dilakukan para khatib di Indonesia juga merupakan rutinitas khatib di negara-negara Arab, dengan nada yang emosional mengecam dan mengutuk Yahudi dan Israel dan mendoakan umat Islam di Palestina agar bisa memenangkan peperangan. Dengan demikian, dukungan

${ }^{13}$ Masyarakat Indonesia kebanyakan melihat hitam putih masalah Palestina.Pemahaman mereka sederhana, Israel dan Yahudi semuanya jahat, sehingga umat Islam harus bersatu membantu Palestina.Padahal, banyak juga orang Yahudi yang mentang pendudukan Israel dan menginginkan perdamaian. Begitupula di Palestina, persoalannya bukan hanya bagaimana perjuangan rakyat Palestina untuk merdeka, tetapi persoalan internal antara Fatah dan Hamas juga cukup rumit.

${ }^{14}$ Selain masalah keagamaan masalah Palestina juga merupakan masalah sosial dan sejarah. Salah satu literatun Indonesia yang membahas hal ini adalah Trias Kuncahyono, dalam Jerusalem: Kesucian, Konflik, dan Pengadilan Akhir (Jakarta: Kompas, 2008). 
muslim Indonesia terhadap isu Palestina pada umumnya tidak bisa dilepaskan dari unsur teologis. ${ }^{15}$

Sepanjang sejarah konflik Palestina, hal yang paling sering dilakukan di Indonesia sebagai bentuk dukungan terhadap muslim Palestina adalah menggelar aksi demonstrasi. Aksi demonstrasi ketika terjadi perang di Palestina khususnya di jalur Gaza dilakukan oleh berbagai kalangan, baik kalangan mahasiswa di kampuskampus, ormas-ormas Islam, partai-partai Islam dan berbagai LSM. ${ }^{16}$ Pada dasarnya aksi demonstrasi yang dilakukan di Indonesia adalah sebagai bentuk kemanusiaan, sebagaimana yang dilakukan oleh komunitas masyarakat lainnya di negara-negara Eropa dan Amerika Serikat. Namun kalau dicermati, aksi-aksi tersebut tidak bisa dilepaskan dari dimensi ideologis karena para pelopor dan massa yang melakukan demonstrasi kebanyakan berasal dari kelompok-kelompok Islam dengan berbagai latar belakan ideologinya, seperti Hizbuttahrir, ${ }^{17}$ Gerakan Tarbiyah ${ }^{18}$ dan lainnya.

${ }^{15}$ Sudah menjadi pemandangan umum bahwa masalah Palestina sering diikutkan dalam ritual keagamaan masyarakat Indonesia sebagaimana yang dilakukan para khatib ketika melakukan khutbah jumat.

${ }^{16}$ Karena banyaknya demonstrasi untuk solidaritas Palestina dilakukan di Indonesia, BBC Indonesia pernah mengangkat isu tentang demo Indonesia, apakah merupakan isu politik atau keagamaan? Diungkapkan bahwa memang benar bahwa kecendrungan masyarakat Indonesia melakukan demo sangat beragam, ada yang politis dan ada juga ideologis.Baca, http://www.bbc.co.uk/indonesia

/berita_indonesia/2014/07/140716_demo_gaza_politik_agama.

${ }^{17}$ Diberitakan Republika, Hizbuttahrir Indonesia menggelar demo besarbesaran di bundarah HI 20 Juli 2014. http:/www.republika.co.id/berita /inpicture/nasional-inpicture/14/07/20/n90oav-aksi-demo-solidaritas-untukpalestina-di-bundaran-hi. Diakses 20 Februari 2015.

${ }^{18}$ Gerakan Tarbiyah merupakan gerakan pendidikan dan pengajaran nilainilai Islam oleh kelompok-kelompok tertentu.Di Indonesia gerakan ini dikembangkan oleh kelompok yang memiliki afiliasi ideologis dengan Ikhwan di Mesir.Gerakan ini pun yang bertransformasi menjadi Partai Keadilan Sejahtera 
Simbol-simbol yang digunakan pun sangat kental dengan nuansa keislaman, seperti kaum perempuan yang ikut aksi memakai jilbab dan tulisan-tulisan dalam umbul-umbul bersimbolkan Islam.

Untuk lebih spesifik lagi, hubungan ideologis antara Hamas dengan masyarakat dan pemerintah Indonesia bisa dilihat dari jaringan partai Islam yang berafiliasi dengan gerakan Ikhwanul Muslimin di Mesir, yaitu Partai Keadilan Sejahtera (PKS). ${ }^{19}$ Mayoritas peneliti dan pakar Islamisme menyatakan bahwa PKS merupakan salah satu dari jaringan partai-partai berhaluan Islam di dunia yang berafiliasi dengan Ikhwan seperti Hamas di Palestina dan AKP di Turki. ${ }^{20}$ Sebagai salah satu Partai Besar di Indonesia, PKS yang didominasi oleh para aktivis Tarbiyah mempunyai dasar-dasar pergerakan yang diadopsi dari pemikiran Ikhwan.Salah satu pemikiran Ikhwan yang sangat berpengaruh terhadap PKS adalah pandangan mengenai pentingnya mengambil langkah politik dalam memperjuangkan Islam.Tanpa melalui jalur politik, mustahil kepentingan Islam bisa tercapai. ${ }^{21}$

(PKS). Selengkapnya baca dalam, "PKS: Implementasi Politik Gerakan Tarbiyah Indonesia dan Pemilu", dalam https:/www.academia.edu/8663909/ PKS Implementasi Politik Gerakan Tarbiyah Indonesia dan Pemilu. Diakses 21 Februari 2015.

${ }^{19}$ Demikian dikatakan Anthony Bubalo, Greg Fealy, Whit Mason dalam Zealous Democrats Islamism And Democracy In Egypt, Indonesia And Turkey (New South Wales: Lowy Institute, 2008), 1-5.

${ }^{20}$ Adalet ve Kalkinma Partisi, (The Justice and Development Party) atau Partai Keadilan dan Pembangunan Turki merupakan partai terbesar saat ini yang didirikan pada tahun 2001 dan dipimpin oleh Recep Tayyip Erdogan. Dinamika Partai ini telah dibahas dengan mendalam oleh Hakam Yavuz, Secularism and Muslim Democracy in Turkey (Camridge: Middle East Studies, 2009).

${ }^{21}$ Pengaruh inilah yang menyebabkan gerakan Tarbiyah Indonesia bertransformasi menjadi partai politik. Anthony Bubalo, Greg Fealy, Whit Mason dalam Zealous Democrats Islamism And Democracy In Egypt, Indonesia And Turkey, 25-30. 
Mulawarman, Respon Muslim Indonesia terhadap Gerakan Islamisme|

169

Sebagai partai yang berhasil masuk dalam pemerintahan, khususnya dalam pemerintaha Presiden Susilo Bambang Yudoyono, PKS banyak memainkan perannya dalam memberikan dukungan terhadap krisis Palestina khususnya krisis Gaza.Peran tersebut bisa diidentifikasi dalam bentuk pernyataan yang dikeluarkan dan dalam bentuk pengirimian bantuan kemanusiaan dengan mengirimkan logistik ke Jalur Gaza.Selain itu, kebanyakan relawan yang tersebar di berbagai organisasi relawan juga memiliki afiliasi doktrin dengan PKS dan Ikhwanul Muslimin. ${ }^{22}$

Setidaknya, itulah bentuk hubungan ideologis antara masyarakat dan pemerintah Indonesia dengan gerakan Hamas. Tidak bisa dipungkiri bahwa hubungan dari sudut pandang pan Islmisme, seperti telah dikemukakan, sangat kuat meskipun belum bisa memberikan pengaruh besar terhadap resolusi konflik dan penyelesaian konflik internal dan eksternal Palestina.

\section{PERSPEKTIF POLITIS DAN HUBUNGAN DIPLOMATIK}

Hubungan Indonesia dengan Palestina dari sudut pandang politik bisa dilihat dari beberapa model.Model yang paling dominan adalah komitmen pemerintah Indonesia untuk mendukung kemerdekaan bangsa Palestina, baik berupa dukungan diplomatik melalui organisasi internasional maupun pernyataan pemerintah untuk mengakhiri krisis Palestina.Dukungan tersebut memang

\footnotetext{
${ }^{22}$ PKS merupakan partai di Indonesia yang kuat mendukung krisis Gaza.Salah bentuk dukungan tersebut seperti yang diberitakan dalan Republika 21 November 2012 bahwa ratusan relawan PKS siap berangkat ke Gaza.http://pksjateng.or.id/index.php/read/news/detail/590/Ratusan-RelawanPKS-Siap-Berangkat-ke-Gaza. Diakses 21 Februari 2015.
} 
sangat beralasan karena dalam sejarah, Palestina dan Mesir termasuk negara pertama yang mengakui kemerdekaan Indonesia. ${ }^{23}$

Dukungan nyata juga diberikan dalam bentuk diplomatik dengan membuka Kedutaan Besar Palestina di Jakarta, meskipun kegiatan kedutaan tersebut sangat minim karena tidak bisa melayani urusan-urasan penting seperti kekonsuleran, sebab Palestina tidak punya otoritas memberikan visa karena masih diblokade Israel. ${ }^{24}$ Dalam hubungan internasional, pembukaan kedutaan merupakan bentuk pengakuan terhadap kedaulatan sebuah negara. ${ }^{25}$

Sebaliknya, sejak berdirinya negara Israel di wilayah Palestina, sampai saat ini, belum pernah ada pengakuan Pemerintah Indonesia terhadap Israel, meskipun pada periode Presiden Abdurrahman Wahid atau Gusdur muncul wacana pembukaan hubungan diplomatik dengan negara Israel. ${ }^{26}$ Namun, wacana itu pun tidak terealisasi karena penentangan yang kuat oleh unsur masyarakat Indonesia, baik dari kalangan ormas Islam, akademisi mapun masyarakat umum.Sampai saat ini tidak ada hubungan diplomatik antara Indonesia dengan Israel dan tidak pernah dibuka

${ }^{23}$ Dukungan Palestina pada saat itu diwakili oleh mufti besar Palestina, Syekh Muhammad Amin Al-Husaini yang secara terbuka mengakui kemerdekaan Indonesia pada 6 September 1944. Saalah satu media yang memuat dukungan ini adalah Surat Kabar al-Ahram di Mesir. http://www.fimadani.com/kemerdekaan-indonesia-berawal-dari-mesir-danpalestina/.

${ }^{24}$ Suatu waktu, penulis pernah berkunjung ke Kedutaan Palestina di Jalan Diponegoro Jakarta, tidak kelihatan kegiatan apa-apa di tempat tersebut.Office Boy di kantor itu pun mengatakan bahwa segala urusan untuk bepergian ke Palestna bisa dilakukan di Kedutaan Yordania.

${ }^{25}$ Lihat dalam Ian Brownlie, Principles of Public International Law, 3rd ed., (Oxford: Oxford University Press, 1979), 345.

${ }^{26}$ Tentang probletika hubungan Israel Indonesia, lihat Irmawan Effendi, "Problematika Hubungan Indonesia-Israel" https:/www.academia.edu/4027495/. 
kedutaan di Jakarta maupun Tel Aviv yang merepresentasikan pemerintahan kedua negara.

Dalam perhelatan pemilihan Presiden Republik Indonesia tahun 2014 yang lalu, salah satu isu yang dimasukkan dalam visi dan misi kebijakan luar negeri masing-masing calon Presiden dan Wakil Presiden -Prabowo Subiyanto-Hatta Rajasa dan Jokowidodo dan Jusuf Kalla- adalah isu Palestina. ${ }^{27}$ Kedua pasangan calon seakan-akan berlomba untuk mempertegas dukungannya terhadap kemerdekaan Palestina.Bahkan salah satu pasangan calon sempat ikut dalam aksi solidaritas mendukung Palestina ketika terjadi perang terakhir di Jalur Gaza. ${ }^{28}$ Keduanya menyadari bahwa isu Palestina merupakan masalah yang didukung oleh mayoritas masyarakat Indonesia sehingga isu ini sangat efektif untuk dijadikan sebagai media kampanye untuk mendapatkan dukungan politik yang lebih besar.Terlepas dari apakah isu ini hanya dijadikan sebagai komuditas politik, atau benar-benar merupakan dukungan yang tulus, yang pasti ini membuktikan bahwa isu politik Palestina menjadi sangat berarti bagi bangsa Indonesia.

Mengenai hubungan Pemeringah Indonesia dengan Hamas, sejak berdirinya organisasi ini tidak mempunyai hubungan formal dengan Hamas.Sampai pada saat Hamas berkuasa setelah memenangkan Pemilu tahun 2006, hubungan politik antara organisasi ini dengan Pemerintah Indonesia tidak terlihat.Ada

\footnotetext{
${ }^{27}$ Berbagai media pun meliput pandangan kedua capres pada waktu itu, terutama dalam debat ketiga. Salah satunya bisa dibaca dalam http://www.tribunnews.com/pemilu-2014/2014/06/23/kubu-jokowi-jk-jokowisatu-sat unya-capres-peduli-palestina-dan-timur-tengah.

${ }^{28}$ Prabowo ikut dalam aksi solidaritas Palestina yang dilaksanakan oleh Komite Nasional untuk Rakyat Palestina (KNRP) 11 Juli 2014.Lihat dalam http://www.muslimdaily.net/berita/nasional/prabowo-ikut-aksi-solidaritas-untukpalestina.html.
} 
beberapa faktor yang menyebabkan tidak adanya hubungan politik antara kedua belah pihak.Di antaranya, secara politik, Hamas tidak merepresentasikan pemerintahan Palestina seperti PLO yang pernah dipimpin oleh mantan Presiden Yasir Arafat, dan selama ini menjalin hubungan dengan negara-negara Islam termasuk Indonesia.

Meskipun demikian, pada beberapa momen, Pemerintah Indonesia, sadar atau tidak, mendukung perjuangan Hamas dalam berbagai pergolakan konflik di Jalur Gaza pada beberapa tahun terakhir.Ketika terjadi perang, Pemerintah Indonesia selalu memberikan dukungan kepada pihak perjuangan Palestina yang diwakili oleh Hamas di Jalur Gaza dan mengecam kebrutalan Israel. ${ }^{29}$ Dalam memberikan dukungan, Pemerintah Indonesia pun terkadang mendapatkan kritikan dari beberapa kalangan.Sebagai contoh, ketika terjadi perang di Gaza, Presiden Susilo Bambang Yudoyono mengeluarkan pernyataan bahwa masalah Palestina sepenuhnya merupakan masalah politik bukan masalah agama.Pernyataan ini dikritik oleh berbagai kalangan yang menganggap bahwa persoalan Palestina tidak bisa dipisahkan dari masalah agama dan politik. ${ }^{30}$

Upaya untuk menjalin hubungan politik dengan Indonesia dilakukan oleh gerakan Hamas baru-baru ini.Pada bulan 2014, delegasi Hamas mengunjungi Indonesia untuk menjajaki pembukaan hubungan politik dengan Indonesia.Delegasi Hamas mengunjungi

\footnotetext{
${ }^{29}$ SBY pada tanggal 31 Juli 2014 mengirimkan surat terbuka kepada masyarakat dunia termasuk PBB untuk mendorong Israel menghentikan serangan ke Jalur Gaza. http://www.republika.co.id/berita/internasional/palestinaisrael/14/07/31/n9ki51-isi-surat-terbuka-sby-tentang-krisis-kemanusiaan-di-gaza. Diakses 21 Februari 2015.

${ }^{30}$ Lihat dalam http://m.inilah.com/news/detail/75203/sby-bisa-terganjalisu-palestina.Diakses 21 Februari 2015.
} 
Mulawarman, Respon Muslim Indonesia terhadap Gerakan Islamisme|

173

Parlemen Indonesia untuk meminta persetujuan terjalinnya hubungan formal antara Indonesia dan Hamas. ${ }^{31}$ Namun, upaya ini tidak berhasil karena berbagai kalangan tidak menyetujui upaya ini termasuk MUI, NU dan Muhammadiyah.Salah satu kelompok yang secara tegas menolak adalah Muhammadiyah yang dinyatakan oleh Din Syamsuddin. Dikatakan oleh Din Syamsuddin, pembukaan hubungan diplomatik antara Pemerintah dengan Hamas akan menjadi masalah karena saat ini Pemerintah memiliki hubungan formal dengan Pemerintahan Resmi Palestina. Makanya harus dihindari dualisme hubungan antara Indonesia dan Palestina.Yang diakui oleh Indonesia hanyalah Pemerintahan Palestina, sedangkan Hamas tidak mewakili otoritas Palestina. ${ }^{32}$

\section{PERSPEKTIF HUMANISME}

Sebagaimana diketahui bahwa ketika terjadi konflik, terutama konflik bersenjata, pasti akan mengakibatkan terjadinya korban kemanusiaan. ${ }^{33}$ Dalam hal ini, konflik Palestina merupakan salah satu konflik yang paling panjang dan menelan banyak korban dari kedua belah pihak.Tidak hanya dari pihak Palestina, dari pihak Israel pun menelan banyak korban.Tetapi, jumlah korban yang jatuh dari pihak Palestina jauh lebih banyak dibandingkan dengan korban

\footnotetext{
31 Pimpinan DPR terima Kunjungan Hamas dalam, http://www.antaranews.com/berita/466697/pimpinan-dpr-terima-kunjunganhamas. Diakses 21 Februari 2015.

32 Pernyataan Din Syamsuddin ini dimuat dalam http://news.metrotvnews.com/read/2014/11/30/325774/ini-alasan-din-tolakhamas-buka-kantor-di-jakarta. Galtung.

${ }^{33}$ Teori tentang konflik, termasuk konflik militer dikaji oleh Johan
} 
dari pihak Israel.Ironisnya, korban yang jatuh dari konflik IsraelPalestina kebanyakan merupakan warga sipil. ${ }^{34}$

Berbicara tentang hubungan Indonesia dengan Hamas di Jalur Gaza dari sudut pandang humanisme, maka yang paling pas untuk dibahas adalah bagaimana upaya komunitas internasional dalam membantu korban kemanusiaan di Palestina. Dalam konteks Indonesia, krisis Palestina senantiasa menjadi keprihatinan masyarakat dan pemerintah, sehingga upaya untuk memberikan sumbangsih dalam masalah ini dilakukan sebagai bentuk solidaritas kemanusiaan, meskipun tidak dipungkiri kuatnya solidaritas keagamaan antara Indonesia dengan Palestina sebagaimana telah dikemukakan sebelumnya. Upaya untuk meberikan bantuan kemanusiaan dilakukan dalam beberapa bentuk.Di antaranya, bantuan dalam bidang pendidikan, kesehatan dan yang paling banyak dilakukan adalah memberikan bantuan finansial.

Dalam bidang pendidikan, walaupun tidak signifikan, masyarakat Indonesia menunjukkan solidaritasnya dengan membangun Rumah Tahfiz Daar al-Qur'an di Gaza yang diprakarsai oleh salah seorang tokoh agama Ustaz Yusuf Mansur. ${ }^{35}$ Tujuan dari pendirian Yayasan ini adalah untuk membantu memberikan fasilitas pendidikan kepada anak-anak Gaza khususnya dalam bidang pendidikan keislaman.Mendirikan Yayasan pendidikan di wilayah konflik tentunya tidak segampang melakukannya di daerah yang tidak berkonflik seperti di Indonesia.Berbagai tantangan dan resiko harus dihadapi. Tantangan dalam bidang finansial sangatlah besar

\footnotetext{
${ }^{34}$ Jumlah korban konflik Palestina sudah sangat banyak meskipun secara detailnya tidak ditemukan datanya.Adapun media internasional yang intens memberitakan konflik ini adalah al-Jazeera dan BBC.

${ }^{35}$ Lihat dalam http://www.pppa.or.id/modul.php?content=berita\&idb=552.
} 
karena sumber dana berasal dari sumbangan masyarakat yang membutuhkan proses yang lama untuk mengumpulkannya. Setelah itu, untuk membawa bantuan dana ke Jalur Gaza harus menggunakan uang tunai dan jumlahnya terbatas karena harus melewati berbagai pemeriksaan baik di Tanah Air maupun di Mesir (perbatasan Gaza). ${ }^{36}$ Setelah sampai di Gaza, untuk membangun infrastruktur resikonya sangat tinggi, karena sewaktu-waktu wilayah tersebut bisa mendapatkan serangan dari militer Israel.Namun karena solidaritas kemanusiaan dan keislaman, para relawan dengan gigih memperjuangkan berbagai bantuan walaupun jumlahnya tidak signifikan.

Bantuan yang cukup signifikan dilakukan oleh masyarakat dan pemerintah Indonesia adalah bantuan langsung berupa uang, makanan, obat-obatan dan infranstruktur kesehatan (rumah sakit).Bantuan ini diberikan melalui lembaga pemerintah, organisasi relawan dan organisasi kemanusiaan internasional.Banyak sekali organisasi relawan yang konsen untuk memobilisasi bantuan ke Palestina khususnya Jalur Gaza. Organisasi-organisasi tersebut: Mercy $^{37}$, Bulan Sabit merah Indonesia (BSMI), ${ }^{38}$ Komite Indonesia

${ }^{36}$ Wawancara dengan salah satu relawan Komite Indonesia untuk Solidaritas Palestina (KISPA). Jakarta, 12 November 2014.

${ }^{37}$ MER-C (Medical Emergency Rescue Committee) adalah organisasi sosial kemanusiaan yang bergerak dalam bidang kegawat-daruratan medis dan mempunyai sifat amanah, profesional, netral, mandiri, sukarela, dan mobilitas tinggi.Organisasi ini telah memberikan bantuan cukup besar terhadap Palestina dan berhasil membangun Rumah Sakit Indonesia di wilayah tersebut.

${ }^{38}$ Bulan Sabit Merah Indonesia atau BSMI merupakan lembaga yang bergerak dalam bidang kesehatan dan sosial di Indonesia dan bekerja sama dengan lembaga kemanusiaan di tingkat nasional, regional dan internasional. Berkaitan dengan konflik Gaza, di awal tahun 2009, relawan BSMI berangkat menuju Palestina saat terjadi bencana kemanusiaan akibat Aksi militer Israel ke daerah Gaza yang merupakan wilayah kedaulatan Palestina. 
untuk Solidaritas Palestina (KISPA), ${ }^{39}$ Komite nasional rakyat Palestina (KNRP), ${ }^{40}$ Dan lainnya. Semua organisasi ini pada dasarnya mempunyai tujuan yang sama yaitu mengumpulkan dana dari masyarakat Indonesia dan menyerahkannya secara langsung ke penduduk Jalur Gaza, baik berupa dana, makanan dan obat-obatan. Salah satu capaian penting dari beberapa organisasi tersebut adalah keberhasilan para relawan Mercy membangun Rumah Sakit di Jalur Gaza.

Militansi para relawan Indonesia untuk membantu rakyat Palestina di Jalur Gaza memang sangatlah besar.Banyak relawan yang sudah bertahun-tahun tinggal di Jalur Gaza dengan misi kemanusiaan.Salah satunya adalah Abdullah Onim, ${ }^{41}$ relawan yang sampai saat ini masih di Jalur Gaza dan juga menjadi koresponden salah satu saluran televisi terkemuka di Indonesia. Dalam peristiwa penyerangan angkatan udara Israel terhadap sebuah kapal yang membawa bantuan logistik ke Jalur Gaza pada bulan Mei 2010, Mavi Marmara dari Turki, beberapa relawan Indonesia juga ikut dalam kapal tersebut -salah satunya ketua KISPA Ustaz Ferry Nour- meskipun tidak ada yang menjadi korban. Kapal ini pun tidak

${ }^{39}$ KISPA termasuk organisasi kemanusiaan di Indonesia yang aktif menyalurkan bantuan ke Palestina.Organisasi ini berdiri pada tanggal 1 Rabiul Awwal $1423 \mathrm{H}$ atau 14 Mei 2002. Bertempat di kantor Majelis Ulama Indonesia (MUI) Masjid Istiqlal organisasi ini dibentuk yang merupakan gabungan dari 20 ormas Islam. Salah satu pendirinya adalah Din Syamsuddin.Baca dalam http://www.eramuslim.com/berita/info-umat/ferry-nur-ketua-kispa-periode-20092014-amanah-ini-akan-saya-jalankan-sepenuhnya.htm.VOk62_mUeuE.Diakses 20 Februari 2015.

${ }^{40}$ Organisasi yang didirikan pada 8 Mei 2006 ini mempunyai peran dalam menyalurkan bantuan ke Palestina.Informasi tentang KNRP bisa dilihat dalam http://www.knrp.org/.

41 Tentang peran Abdullah Onim, baca dalam http://www.pkspiyungan.org/2014/07/sosok-abdillah-onim-relawanindonesia.html. 
Mulawarman, Respon Muslim Indonesia terhadap Gerakan Islamisme| 177

berhasil menembus Jalur Gaza karena dihadang oleh militer Israel.Peristiwa ini kemudian mendapat kecamana internasional termasuk Pemerintah Indonesia. ${ }^{42}$

Sampai saat ini, aktivitas para relawan sangat terbatas karena sulitnya untuk memberikan bantuan ke Jalur Gaza.Setelah jatuhnya Presiden Muhammad Mursi pada pertengahan 2014, yang dikudeta oleh Presiden Muhammad al-Sisi saat ini, Jalur Gaza tidak bisa lagi ditembus oleh para relawan karena sikap pemeritah Mesir yang sangat represif terhadap Ikhwan.Pemerintah Mesir menutup perbatasan Rafah karena khawatir terjadinya interaksi yang intens antara kelompok Hamas dan Ikhwan di Mesir.

Dari analisis yang dilakukan dalam bab ini, dapat disimpulkan bahwa dalam perspektif konflik high politic, pan Arabisme masih menjadi salah satu landasan yang kuat dalam pola hubungan negara-negara Arab.Meskipun tidak bisa dipungkiri bahwa relasi antara negara-negara Islam dan Arab juga dilandasi oleh kepentingan politik.Dalam kasus Palestina, negara-negara Arab pada umumnya tetap mempertahankan hubungan dengan kelompok Islamisme Hamas. Hal tersebut dilakukan dalam berbagai model, dalam bentuk dukungan moral, finansial atau retoris. Hubungan tersebut menjadi faktor penting sehingga Hamas bisa eksis dalam konstalasi politik Palestina.Namun, tingkat partisipasi Arab dan komunitas internasional dari satu negara dengan yang lainnya bervariasi, tergantung prospek dan kepentingan masing-masing.

Dukungan negara Islam terhadap kelompok Islamis juga tidak bisa dilepaskan oleh kepentingan politik dan unsur

${ }^{42}$ Kronologi dari peristiwa bisa dibaca dalam http://www.voaislam.com/read/indonesiana/2010/06/03/6707/kisah-relawan-indonesia-saatpenyerbuan-kapal-mavi-marmara/;sthash. 
sektarianisme.Keberadaan Iran dan negara Arab lainnya dalam kasus Hamas tidak bisa dipisahkan dari persaingan Sunni dan Syi'ah.Sedangkan sampai saat ini, padangan Barat secara umum terhadap kelompok Islamis masih cenderung negatif dengan mengaggap Hamas sebagai salah satu institusi teroris.Terakhir, dalam hal hubungan Indonesia dengan Hamas, tidak bisa dipisahkan dari tiga sudut pandang; sudut pandang Pan Islamisme, politik dan Humanisme.Akumulasi dari tiga isu ini menjadikan hubungan antara Indonesia dan Hamas dianggap cukup kuat.

\section{KESIMPULAN}

Hubungan Hamas Indonesia terjadi dalam tiga bentuk; ideologis (Pan Islamisme), politis dan humanism.Dari sudut pandang Pan Islamisme, masyarakat Indonesia selalu mendukung Hamas dalam berbagai ekspresi. Mendoakan rakyat Palestina dalam khutbah jumat, menggelar aksi dukungan dan lain-lain merupakan bentuk ekspresi masyrakat muslim Indonesia terhadap perjuangan rakyat Palestina (Hamsa). Dari sudut pandang politik, pemerintah Indonesia selalu mendukung perjuangan Palestina untuk merdeka, baik dalam bentuk pernyataan maupun lewat organisasi internasional.Dari sudut pandang humanisme, Indonesia termasuk negara yang banyak memberikan bantuan kemanusiaan ke Jalur Gaza.

\section{DAFTTAR PUSTAKA}

Ali Abunimeh, "Hamas and the Two State Solution: Villain, Victim, or Missing Ingredient, "Middle East Policy, Vol. XV, No. 3, (2008).

Sherifa Zuhur, "Hamas and Israel: conficting Strategies of GroupBased Politic",dalam Nejc Kardelj (ed.), Israel Versus Hamasi (New York: Nova Science Publishers, 2010). 
Mulawarman, Respon Muslim Indonesia terhadap Gerakan Islamisme|

179

Michael Irving Jensen, The Political Ideology of Hamas: A Grassroots Perspective (New York: I.B. Tauris, 2009).

Kuel Jok, "Conflict of National Identity in Sudan" Academic Dissertation, University of Helsinki, (2012).

Osama Abu Rashid dan Paul Syam, "Hamas: Tashaddud 'Aqa'idiwa Murunah Siyaasiyyah", Silsilah Tarjamat al-Zaitunah 47, (Januari 2010).

Robert Satloff, "Origins, Tactics, Strategy, and Response" dalam Hamas Triumphant, Implication for Security, Politics, Economy, and Strategy, The Washington Institute for Near East Policy (2006).

Abu Nimr tentang studi perdamaian bisa dilihat dalam Muhammad $\mathrm{Abu}$ Nimer, Nonviolence and Peacebuilding in islam (Florida: University Press of Florida, 2003).

Mahmud Zihar, Ishkaliyyah al-Khitab al-Siyasi al-Islami al-Mu'asir (Beirut: Dar al-Mustaqbal, tt.).

Ashraf al-‘Ajrami, “al-Mar' ah wa al-Intikhabat” Majallah Tasamuh, Edisi 5, (2004).

Ali Abunimeh, "Hamas and The Two State Solution:Villain, Victim, or Missing Ingredient," Middle East Policy, Vol. $X V$, No. 3, Summer 2008.

Jim Zanotti (ed.), "Israel and Hamas: Conflict in Gaza (2008-2009)" Congressional Research Service, (Februari 2009).

Aaron D. Pina, "Fatah and Hamas: the New Palestinian Factional Reality", CSR Report for Congress (Maret 2006), 2.

Khalid al-Hindi, 'Amaliyyah al-Bina al-Watani al-Filistini, Wijhah Nazrin Islamiyyah (Nablus: Markaz al-Buhuth wa al-Dirasat al-Filistiniyyah, 1999). 
Jamal Mansur, al-Tahawwul al-Dimuqrati al-Filistini Wijhah Nazr Islamiyyah (Nablus: Markaz al-Buhuth wa al-Dirasat alFilistiniyyah, 1999).

Mahmud al-Zihar, al-Qawasim al-Mushtarakah wa Wihdat al-Hadf fi al-Sultah wa al-Mu'aridah (Ramallah: Manshurat Wizarah al-I'lam, 1995).Boris Dewiel, Democracy; A History of Ideas (Canada: University of British Columbia Press).

David Potter, David Goldblatt, Margaret Kiloh, Paul Lewis, Democratization(USA: Polity Press in Assosiation with the Open University, 2000).

John L. Esposito \& John O. Voll, Islam and Democracy (New York: Oxford University Press, 1996).

Komaruddin Hidayat dan Ahmad Gaus AF (ed.). Islam Negara dan Civil Socierty (Jakarta: Paramadina, 2005), 279.

Majid Khadduri, Arab Contemporaries, the Role of Personalities in Politics (Baltimore and London: The Johns Hopkins University Press).

Hakan Yilmaz, "Islam, Sovereignty, and Democracy: A Turkish View”, Middle East Journal, Vol. 61, No. 3 (Summer, 2007).

David Held, Models for Democracy (London: Blackwell Publisher, 2000), 294.

Sami Zubaida, Islam the People and the State: Polical Ideas and Movements in the Middle East (London: I.B. Tauris, 2009).

Abu al-A'la al-Maududi, The Polical Theory of Islam (Pathankot:

Maktab al-Jama' at al-Islami,tt).

Youssef M. Choueriri, Islamic Fundamentalism (London, 1990).

Ayatullah Khumaini, “An Islamic State: Point of View” dalam

Salim Azzam, (ed.), Concept of Islamic State (Kuala Lumpur:

ABIM 